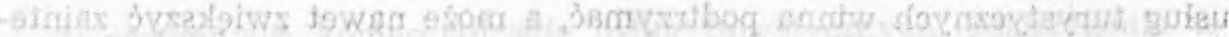
"TURYZM" 1991, z. 2

Teofil Lijewski

\title{
ZADANIA DLA GEOGRAFII TURYZMU
}

\section{LES TÂCHES QUE DOIT REMPLIR LA GEOGRAPHIE DU TOURISME}

\section{TASKS FOR GEOGRAPHY OF TOURISM}

W geografii turyzmu można wyróżnić 3 kierunki, wyraźnie różniące się zakresem tematycznym badań:

1) geografię walorów turystycznych (przyrodniczych i antropogenicznych);

2) geografię zagospodarowania turystycznego;

3) geografię ruchu turystycznego.

Walory turystyczne badało i klasyfikowało już wielu autorów. Dążono do ujęć ilościowych i zapisów sformalizowanych, dzieląc np. teren na równe kwadraty i obliczając ich atrakcyjność na podstawie różnic wysokości, udziału wód, powierzchni leśnej itp. Spośród walorów antropogenicznych najbardziej sformalizowana została klasyfikacja zabytków (podział na klasy hierarchiczne).

Subiektywne odczuwanie piękna krajobrazu i jego przekształceń przez człowieka często nie jest zgodne z obliczonymi, pozornie obiektywnymi wskaźnikami. Na przykład duży udział powierzchni leśnej nie zawsze podnosi atrakcyjność krajobrazu, niekiedy bardziej malownicze są pojedyncze drzewa i krzewy lub ich kępy. Bardziej istotna jest różnorodność krajobrazu, bogactwo jego szczegółów w zasięgu wzroku. Można to stwierdzić tylko doświadczalnie na miejscu, mało przydatne są tu mapy i dane statystyczne.

$\mathrm{Na}$ ogól negatywnie ocenia się ingerencję człowieka w przyrodę. Tymczasem dzieła rąk ludzkich (nie tylko artystyczne) mogą także ożywić i urozmaicić krajobraz. Swiadczą o tym pejzaże wybitnych mistrzów. Niestety sharmonizowane $\mathrm{z}$ otoczeniem dawne budowle, jak chałupy wiejskie, młyny wodne, wiatraki, drewniane mostki, znikają, zastępowane przez „nowoczesność" w postaci betonu, pustaków, papy i eternitu. 
Niedocenianymi przez nas walorami turystycznymi są relikty dawnej techniki, atrakcyjne zwłaszcza dla przybyszów z krajów bardziej rozwiniętych. Można tu wymienić przykładowo zastosowanie koni w rolnictwie, furmanki, szachownicę pól, dawne rzemiosła (np. kowalstwo, ciesielstwo, bednarstwo), stare zakłady przemyslowe z zachowanymi dawnymi urządzeniami i maszynami, parowozy, kolejki wąskotorowe, stare tramwaje, statki itd. Część tych reliktów należałoby zachować w ich naturalnym otoczeniu i udostępnić do zwiedzania. Zabytkowy zakład przemysłowy, uruchamiany pokazowo, może też stanowić źródło dochodu dla firmy lub miejscowości.

Zadaniem geografów może być wyszukiwanie takich obiektów, planowanie tras pokazowych, wskazywanie samorządom terytorialnym możliwości ekspozycji takich reliktów przeszłości. Naszego zacofania technicznego nie zawsze trzeba się wstydzić, nieraz można je dobrze sprzedać.

Zagospodarowanie turystyczne badano zwykle dość szablonowo, ograniczając się nieraz tylko do obiektów noclegowych (hotele, schroniska, domy wczasowe, kempingi). Już to prowadziło do błędnych wniosków, ponieważ nie uwzględniano kwater prywatnych, o ile nie były rejestrowane przez przedsiębiorstwa turystyczne. Pauperyzacja ludności prowadzi do tego, że coraz częściej korzysta się z kwater prywatnych, rodzinnych, $u$ znajomych itp. Podobnie $z$ pola widzenia statystyki turystycznej umykają szkoly, domy studenckie, internaty i inne masowe kwatery, wynajmowane sezonowo koloniom, obozom dziecięcym i młodzieżowym. Pomija się również obozy harcerskie organizowane poza obiektami stałymi.

Badać należałoby także infrastrukturę paraturystyczną, służącą m. in. turystyce, jak sieć komunikacyjną, gastronomiczną, handlową, ze szczególnym uwzględnieniem urządzeń niezbędnych do ruchu turystycznego, jak stacje benzynowe, parkingi przydrożne, warsztaty samochodowe.

Szczególnie niepełna jest nasza wiedza odnośnie do tej formy rekreacji, która rozwija się ostatnio najszybciej, tj. budownictwa letniskowego i działek rekreacyjnych. Temat ten został pominięty $\mathrm{w}$ ostatnim spisie powszechnym, mimo że dokonywano szczegółowej inwentaryzacji miejscowości. Interesujące byłoby badanie z 2 stron: od strony gminy, na terenie której powstały domki letniskowe i działki rekreacyjne (kto je zakupił, skąd dojeżdża) i od strony wielkich miast (dokąd mieszkańcy wyjeżdżają, gdzie zakupują tereny).

Obiektami zbliżonymi charakterem do działek rekreacyjnych są ogródki działkowe; wobec deficytu terenów w miastach oddalają się one od miejsc zamieszkania i wymagają nieraz dojazdu równego wycieczce weekendowej.

Wszystkie te formy rekreacji podmiejskiej i pozamiejskiej należałoby 
badać łącznie, najlepiej w postaci studiów monograficznych poszczególnych aglomeracji czy regionów. Pożądane byłoby sporządzanie szczególowych map użytkowania terenu oraz prześledzenie zmian w czasie, np. przez porównanie map topograficznych i zdjęć lotniczych z różnych okresów.

Badania zagospodarowania turystycznego mogą być utrudnione przez postępującą obecnie prywatyzację obiektów. Prywatni właściciele nie będą zainteresowani sprawozdawczością i udzielaniem informacji o swoich obiektach. Zmaleje udział organizacji państwowych i ogólnopolskich, jak FWP, „Orbis”, PTTK, z którymi łatwiej było współpracować, i które gromadziły materiały z całego kraju.

Ruch turystyczny jest najbardziej nieuchwytny statystycznie. Wszystkie szacunki jego rozmiarów były niedokładne, toteż zaprzestano ich publikacji. Ewidencją objęty jest tylko ruch zorganizowany, korzystający $z$ obiektów noclegowych i przewodników. Tymczasem zwiększa się udzial ruchu indywidualnego, który często nie korzysta z żadnych urządzeń turystycznych. Również powstające obecnie masowo prywatne biura podróży prawdopodobnie nie ułatwią badań geograficznych.

Geografów powinien interesować rozkład ruchu turystycznego w przestrzeni (skąd, dokąd, którędy) i w czasie. Zaznacza się bardzo silna koncentracja ruchu w przestrzeni, na określonych szlakach i w najbardziej atrakcyjnych regionach. Na przykład gęstość ,zaludnienia” plaż nadmorskich w sąsiedztwie miejscowości wypoczynkowych w pogodny dzień letni jest podobna do gęstości zaludnienia wysokościowych osiedli mieszkaniowych w wielkich miastach, z których właśnie wyjeżdża się na wczasy, aby uciec od tłumu. Nie lepiej jest w górach: deptaki Doliny Kościeliskiej czy drogi do Morskiego Oka nie ustępują zatłoczeniem najbardziej ruchliwym ulicom śródmiejskim.

Równocześnie istnieją w Polsce rozległe tereny, atrakcyjne krajobrazowo, prawie zupełnie nie odwiedzane przez turystów. Można je znaleźć na wybrzeżu, a tym bardziej na pojezierzu i w górach. Jedną z przyczyn małego zainteresowania jest brak zagospodarowania, inną - niedogodny dojazd lub konieczność dalekiego dojścia pieszego. Ale nieraz główną przyczyną jest brak informacji i reklamy danego terenu. Tutaj geografowie mogliby odegrać bardzo pożyteczną rolę, wyszukując i propagując tereny odpowiednie do deglomeracji ruchu.

Natomiast tereny o przekroczonej chłonności turystycznej należałoby ogłosić regionami klęski ekologicznej (turystycznej), analogicznie do regionów o nadmiernie zanieczyszczonym powietrzu i wodzie (zresztą turystyka przyczynia się do tego zanieczyszczenia w dużym stopniu). W regionach klęski ekologicznej należałoby ograniczyć ruch turystyczny, 
np. poprzez zakaz organizacji zakladowych wycieczek zbiorowych (zwykle najbardziej dewastujących środowisko) lub zakaz ruchu samochodowego.

Deglomerację ruchu w czasie można osiągnąc przez zmianę przyzwyczajeń, inny rozkład czasu pracy, a zwłaszcza przez zróżnicowanie terminów wakacji szkolnych i studenckich. Na skutek sztywnego stanowiska resortu edukacji narodowej prawie nie wykorzystany na wypoczynek dzieci i młodzieży jest czerwiec - miesiąc o największym usłonecznieniu, zwykle pogodniejszy od lipca.

Badania ruchu turystycznego są żmudne i pracochłonne, $z$ reguły wymagają obserwacji terenowych. Należałoby wykorzystać w tym celu praktyki, obozy i wczasy studenckie i młodzieżowe. Ponieważ coraz większy udział w ruchu turystycznym mają samochody, pomocne może być odczytywanie województwa ich pochodzenia według tablic rejestracyjnych.

Geografowie powinni nie tylko badać rzeczywistość, ale i starać się ją kształtować. Powinni chronić najcenniejsze przyrodniczo fragmenty naszego kraju, wytyczając inne szlaki dla masowej turystyki i propagując regiony mniej znane. Ważna jest więc działalność informacyjna, do której są powołani jako najbardziej kompetentni znawcy kraju.

W większym niż dotychczas stopniu geografowie powinni brać udział w opracowywaniu przewodników, map turystycznych, artykułów w czasopismach krajoznawczych, filmów, audycji radiowych i telewizyjnych. Ich nieobecność powoduje, że przewodniki są przeładowane szczegółami historycznymi, opisami zabytków i dzieł sztuki, pomijając równocześnie elementy geograficzne - jak położenie, rzeźbę terenu, budowę geologiczną, hydrografię, przyrodę ożywioną i gospodarkę. To samo odnosi się do informacji o Polsce dla cudzoziemców. Jej brak lub niski poziom jest jedną z przyczyn małego zainteresowania Polską na międzynarodowym rynku turystycznym i znikomego udziału turystyki w dewizowych dochodach Polski.

Prof. dr hab. Teofil Lijewski

Instytut Geografii

i Przestrzennego Zagospodarowania

Wpłynęlo:

Polskiej Akademii Nauk

Warszawa

ul. Krakowskie Przedmieście 30

00-927 Warszawa 